\title{
ARTICLE
}

\section{Comparison of ecological diversity and species composition of macroalgae, benthic macroinvertebrates, and fish assemblages between two tropical rocky reefs}

Comparación de la diversidad ecológica y composición de especies de ensambles de macroalgas, macroinvertebrados bentónicos y peces en dos arrecifes rocosos tropicales

\section{Verónica C. García-Hernández ${ }^{1,2}$, Héctor Reyes-Bonilla ${ }^{3}$, Eduardo F. Balart ${ }^{1}$, Eduardo Ríos-Jara ${ }^{4}$, Salvador E. Lluch-Cota ${ }^{1}$ and Elisa Serviere-Zaragoza ${ }^{1}$}

\author{
'Centro de Investigaciones Biológicas del Noroeste (CIBNOR), La Paz, B.C.S. 23096, México. serviere04@cibnor.mx \\ ${ }^{2}$ Instituto Tecnológico de Bahía de Banderas Nayarit, Bahía de Banderas, Nayarit. 63734, México \\ ${ }^{3}$ Universidad Autónoma de Baja California Sur, La Paz, B.C.S., 23080, México \\ ${ }^{4}$ Universidad de Guadalajara, Centro Universitario de Ciencias Biológicas y Agropecuarias, Predio Las Agujas, Zapopan, \\ Jalisco, México
}

\begin{abstract}
Resumen.- En el medio marino, las costas rocosas son reconocidas por su alta diversidad de especies y particularmente las zonas de transición representan áreas de mezcla biótica, provocado por las variaciones naturales históricas y ecológicas que permiten la presencia de taxones de diferentes regiones y que presentan rasgos biológicos diferentes. Un estudio intensivo permitió describir los ensambles de macroalgas, macroinvertebrados (moluscos, crustáceos y equinodermos) y de peces en dos arrecifes rocosos: Islas Marietas y Tehuamixtle, en la zona de transición tropical-templado en el norte del Pacífico de México, utilizando índices ecológicos tradicionales (riqueza, diversidad y uniformidad) y complementando con índices de distinción taxonómica. Se colectó el material biológico de 10 cuadrantes $(25 \times 25 \mathrm{~cm})$ ubicados aleatoriamente a lo largo de dos transectos de $50 \mathrm{~m}$ paralelos a la línea de costa, a una profundidad de entre 6 y $12 \mathrm{~m}$. Se identificaron 204 especies: 22 macroalgas, 55 moluscos, 78 crustáceos, 11 equinodermos y 38 peces. La estructura de la comunidad de macroalgas, macroinvertebrados y peces fue similar entre los sitios. Macroalgas, moluscos y peces fueron más diversos en verano y crustáceos y equinodermos fueron más diversos en el invierno. Los resultados y la literatura sugieren un patrón latitudinal de menores cambios estacionales en equinodermos y crustáceos en las altas respecto a bajas latitudes en el Pacífico mexicano.
\end{abstract}

Palabras clave: Biodiversidad, macrobentos, arrecifes rocosos, distintividad taxonómica

Abstract.- Within the marine environment, the rocky shores are recognized for their high species diversity and particularly transitional zones represent areas of biotic mix, promoted by historical and ecological natural variations that allow the presence of taxa from different regions and which present dissimilar biological traits. An extensive survey describes the benthic macroalgae, macroinvertebrates (molluscs, crustaceans, and echinoderms), and fish assemblages at two rocky reefs, Islas Marietas and near Tehuamixtle, in a tropical-temperate transitional zone in the Pacific waters of central Mexico using traditional ecological indices (richness, diversity, and evenness) and complementary taxonomic distinctness indices. Biological material inside each of ten randomly-chosen quadrants $(25 \times 25 \mathrm{~cm})$ placed along two $50 \mathrm{~m}$ transects oriented parallel to the coastline, between 6 and $2 \mathrm{~m}$ depth was collected. From field collections, 204 species were identified: macroalgae (22), molluscs (55), crustaceans (78), echinoderms (11), and fish (38). The structure of macroalgae, macroinvertebrates and fishes was similar between sites. Species of macroalgae, molluscs, and fishes were more diverse in summer; crustaceans and echinoderms were more diverse in winter. Our results and the literature suggest a latitudinal pattern of lower seasonal changes in echinoderms and crustaceans at high latitudes, as compared to southern regions of the Mexican tropical Pacific.

Key words: Biodiversity, macrobenthos, rocky reefs, taxonomic distinctness

\section{INTRODUCTION}

Rocky shores are widely recognized for their high species diversity; they are among the best understood marine ecosystems, concentrating many descriptive and experimental scientific works (Dayton 1971, Menge 1976, Wootom 1993, Underwood 2000). Rocky reefs are complex environments with benthic assemblages of flora and fauna 
showing high heterogeneity in their composition and structure at different scales of time and space (Kaehler \& Williams 1998), and immerse in diverse interactions such as predation and competition for food and space (Menge 1976, Dayton \& Tegner 1984, Underwood \& Chapman 1998).

Transitional zones are the boundaries between climatic realms, in this case the tropical and subtropical. This situation results in strong seasonality, as the tropical conditions tend to prevail during the summer and subtropical during the winter. In the ocean, they represent areas of biotic mix, promoted by historical and ecological natural variations that allow the presence of taxa from different regions and which present dissimilar biological traits (Zajac et al. 2003, Morrone 2009, Anderson et al. 2012). These zones deserve special attention because they commonly correspond to boundaries between biogeographic regions, typically in the scale of thousands of kilometers, where intense biotic interactions occur (Ruggiero \& Ezcurra 2003, Anderson et al. 2012).

In the northern part of the Mexican tropical Pacific, the study of rocky reefs benthic communities has been mostly devoted to the collection of basic information about the distribution and abundance of particular taxonomic groups and only few examples exists where these systems are analyzed at the ecosystem level (CONANP 2007). Species composition and abundance of macroalgae (Enciso-Padilla \& Serviere-Zaragoza 2006), molluscs (RíosJara et al. 2006), crustaceans (Gasca 2009), echinoderms (Ríos-Jara et al. 2008, 2013) and fishes (Castro-Aguirre et al. 2006, Chávez-Comparán et al. 2006) have independently shown that this area is inhabited by species from different biogeographic domains, namely the Gulf of California, the Eastern Tropical Pacific, and even some temperate species that move southward during the winter (Robertson \& Allen 2008).

Our objective was to compare the structure and composition of benthic flora, macroinvertebrates, and fish assemblages at two rocky reefs located in the transitional area between the tropical and subtropical northeastern Pacific, using traditional ecological indices (richness, diversity, and evenness) as well as taxonomic distinctness indices (which offer complementary information), to test the hypothesis that because of the strong seasonality that exists in these type of transitional systems, all taxonomic groups would show very intense seasonal differences in species composition and dominance.

\section{MATERIALS AND METHODS}

\section{STUDY SITES AND SAMPLING}

We studied 2 sites from the Bahía de Banderas, Mexico area: Islas Marietas and near Tehuamixtle (Fig. 1), these areas are located between the Cortes and Mexican biogeographic provinces (Briggs 1974). Both sites show rocky reefs at depths of 6 to $12 \mathrm{~m}$. Main differences between sites include physiographic conditions and the environmental protection status; Islas Marietas is considered a RAMSAR area, while Tehuamixtle receives no specific conservation efforts.

The mesoscale ocean circulation is determined by the convergence of three ocean current systems: (a) the cold California Current flowing to the Southeast, (b) the warm Costa Rica Current, flowing northward, and (c) the warm water from the Gulf of California that reaches the area during fall and winter (Badán 1997). Strong annual amplitude in the climate signal results in well-defined winter and summer seasons (CNA 2012). We recorded in situ water temperatures along an annual cycle using $\mathrm{HOBO}$ sensors, located at $6 \mathrm{~m}$ depth and programmed to register every $30 \mathrm{~min}$, registering monthly mean values between $19.4^{\circ} \mathrm{C}$ in February and $29.7^{\circ} \mathrm{C}$ in July (unpublished data). Salinity near the coastline is strongly affected by rivers runoff and seasonal precipitation; a rainy period during June to October and a dry period during the rest of the year (November to May; Hernández-Herrera et al. 2005). Long term, low resolution water temperature data (Reynolds et al. 2012), also showed a well-defined seasonal cycle.

\section{Structure of the assemblages and Statistical ANALYSIS}

To cover both spatial and temporal differences, Islas Marietas and Tehuamixtle were visited 2 times during the summer (September 2010 and July 2011) and also twice in winter (December 2010 and March 2011). At each visit, we collected by hand (scuba-diving) all macroalgae, molluscs, crustaceans, and echinoderms specimens inside each of ten randomly-chosen quadrants $(25 \times 25 \mathrm{~cm})$ placed along two $50 \mathrm{~m}$ transects oriented parallel to the coastline, at two depths 6-9 m and 9-12 m depth $(n=20)$, for a total of 160 quadrants. The specimens were placed in labeled plastic bags and preserved in a 0.10 formalin-seawater (1:9) solution. 


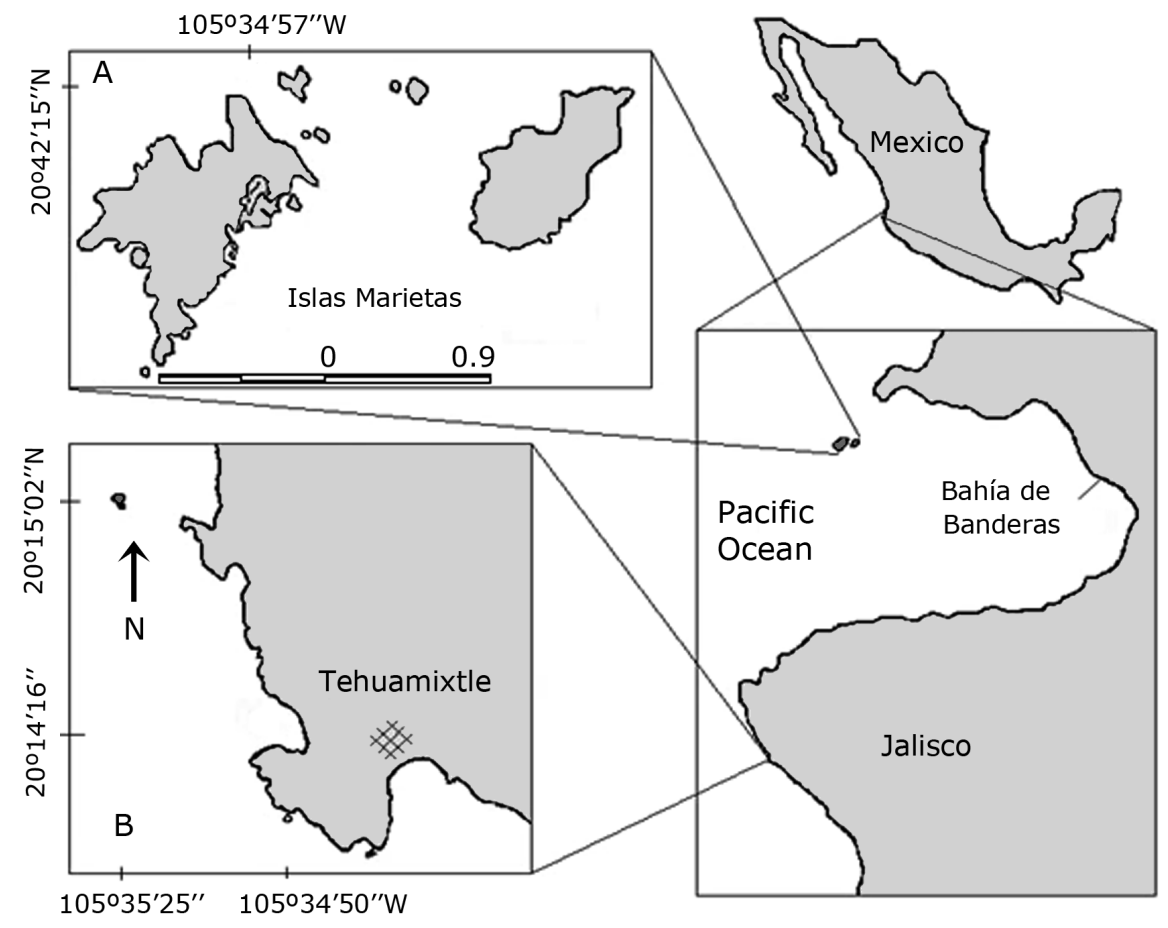

Figure 1. Study sites. (A) Islas Marietas in the State of Nayarit and (B) Tehuamixtle in the State of Jalisco / Sitios de estudio. (A) Islas Marietas en el Estado de Nayarit y (B) Tehuamixtle en el Estado de Jalisco

For fishes, 2 videos were taken along the $50 \times 2 \mathrm{~m}$ belt transects at each site and visit. In the videos, a diver filmed the fishes observed along the belt transect, during periods ranging between 4 to $5 \mathrm{~min}$, depending on the habitat complexity and the environmental conditions. The videos were later revised to count all individuals and identify the species in the entire sampled area $\left(100 \mathrm{~m}^{2}\right)$.

In the laboratory, we weighted the fronds of each macroalgae sample $( \pm 0.1 \mathrm{~g})$, and counted all molluscs, crustaceans, and echinoderms. All samples were identified to the lowest possible taxonomic level.

To confirm the completeness of the species inventory we applied Jackknife 1 and Bootstrap statistical tests using PRIMER-6 software (PRIMER-E, Ivybridge, UK; Clarke \& Gorley 2006). To describe the community structure for each group and sample, we computed classic descriptors: species richness $(\mathrm{S})$, abundance $(N$; total wet weight in grams for the macroalgae, and total number of molluscs, crustaceans, echinoderms, and fish individuals),
Shannon-Wiener diversity index $\left(H^{\prime}\right)$, and evenness $\left(J^{\prime}\right)$. Also, we estimated average taxonomic distinctness $\left(\Delta^{+}\right)$ and variation in taxonomic distinctness $\left(\Lambda^{+}\right)$at each transect, based on presence-absence records. These measures provide a summary of the relatedness between organisms and incorporate the identity of species from a sample by considering the average path length between all pairs of species, measured through a Linnaean classification tree. The $\Delta^{+}$index requires only a species list for calculation and a detailed taxonomic classification. It is unbiased to differences in species richness, and to sampling effort (Clarke \& Warwick 1998).

For $\Delta^{+}$and $\Lambda^{+}$, taxonomic trees were prepared to include macroalgae, molluscs, crustaceans, echinoderms, and fish at all taxonomic levels. The classifications were based on Algaebase ${ }^{1}$, the International Taxonomic Information System $^{2}$ for macroinvertebrates, and Nelson (2006) for fish. When a higher taxonomic category was non-existent in a particular species (i.e., suborder or subfamily), we

\footnotetext{
${ }^{1}<w w w$. algaebase.org $>$

${ }^{2}<$ www.itis.gov $>$
} 
assigned dummy names for the taxa that needed it, in order to standardize the topology tree and have a common format. All analyses of taxonomic diversity were performed using PRIMER-6 software (PRIMER-E, Ivybridge, UK; Clarke \& Gorley 2006) and assuming proportional weight to each higher taxonomic level.

Once the values of all indices were calculated, we used a permutational multivariate analysis of variance (PERMANOVA; Anderson 2001) to determine the community structure differences for macroalgae, molluscs, crustaceans, echinoderms, and fishes, analyzing each taxonomic group independently, and using sites and seasons as factors. Later, the Bray-Curtis coefficient was used to compare composition similarity between sites and seasons and a non-metric multidimensional scaling (NMDS) ordination based on the full matrix was built to graphically represent the assemblage's patterns. As a complement, we used the SIMPER test (dissimilarity percentage analysis; calculated with PRIMER-6) to identify those species that contributed the most to the qualitative differences found between sites and seasons.

Table 1. PERMANOVA based on Bray-Curtis dissimilarities of $\mathrm{S}$, richness; $\mathrm{N}$, wet weight in grams for the macroalgae, and number of individuals; J', Pielou's evenness; H', Shannon-Waver diversity; $\Delta^{+}$, average taxonomic distinctness; $\Lambda^{+}$, variation in taxonomic distinctness of macroalgae, molluscs, crustaceans, echinoderms and fish at 2 sites during 2 seasons in the southeastern Gulf of California. IM = Islas M arietas, TE=Tehuamixtle. (*P < 0.05; ** P < 0.01) / PERMANOVA basado en la disimilaridad de Bray-Curtis de la $\mathrm{S}$, riqueza; $\mathrm{N}$, biomasa en gramos de peso húmedo para macroalgas y número de organismos; J', equidad de Pielou; $\mathrm{H}^{\prime}$, diversidad de Shannon-Waver; $\Delta^{+}$, promedio de distintividad taxonómica; $\Lambda^{+}$, variación de distintividad taxonómica de macroalgas, moluscos, crustáceos, equinodermos y peces en 2 sitios durante 2 estaciones al sureste del Golfo de California. IM= Islas Marietas, $T E=$ Tehuamixtle. $(* P<0,05 ; * *<<0,01)$

\begin{tabular}{|c|c|c|c|c|c|c|c|c|c|}
\hline \multirow{2}{*}{ Index } & \multicolumn{3}{|c|}{ Sites } & \multicolumn{3}{|c|}{ Seasons } & \multicolumn{3}{|c|}{ Sites $\mathrm{X}$ season } \\
\hline & $\mathrm{F}$ & $P$ & d.f. & $\mathrm{F}$ & $P$ & d.f. & $\mathrm{F}$ & $P$ & d.f. \\
\hline \multicolumn{10}{|c|}{ Macroalgae } \\
\hline $\mathrm{S}$ & 2.82 & 0.072 & 1,159 & 8.86 & $0.005 * *$ & 1,159 & 0.95 & 0.330 & 1,159 \\
\hline $\mathrm{N}$ & 2.37 & 0.063 & 1,159 & 6.39 & $>0.01 * *$ & 1,159 & 2.31 & 0.066 & 1,159 \\
\hline$H^{\prime}$ & 0.78 & 0.403 & 1,159 & 9.88 & $>0.01 * *$ & 1,159 & 0.77 & 0.405 & 1,159 \\
\hline $\mathrm{J}^{\prime}$ & 0.69 & 0.439 & 1,159 & 9.85 & $0.001 * *$ & 1,159 & 0.77 & 0.404 & 1,159 \\
\hline$\Delta^{+}$ & 0.74 & 0.410 & 1,159 & 10.52 & $>0.01 * *$ & 1,159 & 0.98 & 0.313 & 1,159 \\
\hline$\Lambda^{+}$ & 0.36 & 0.662 & 1,159 & 9.91 & $>0.01 * *$ & 1,159 & 0.37 & 0.655 & 1,159 \\
\hline \multicolumn{10}{|l|}{ Molluscs } \\
\hline $\mathrm{S}$ & 0.62 & 0.455 & 1,159 & 18.51 & $>0.01 * *$ & 1,159 & 0.33 & 0.627 & 1,159 \\
\hline $\mathrm{N}$ & 4.69 & $0.015 * *$ & 1,159 & 0.87 & 0.394 & 1,159 & 2.90 & 0.066 & 1,159 \\
\hline$H^{\prime}$ & 3.62 & 0.058 & 1,159 & 0.36 & 0.604 & 1,159 & 0.85 & 0.365 & 1,159 \\
\hline $\mathrm{J}^{\prime}$ & 3.66 & 0.053 & 1,159 & 0.40 & 0.556 & 1,159 & 0.85 & 0.381 & 1,159 \\
\hline$\Delta^{+}$ & 0.04 & 0.931 & 1,159 & 28.70 & $>0.01 * *$ & 1,159 & 0.55 & 0.447 & 1,159 \\
\hline$\Lambda^{+}$ & 1.72 & 0.152 & 1,159 & 9.38 & $>0.01 * *$ & 1,159 & 1.27 & 0.274 & 1,159 \\
\hline \multicolumn{10}{|c|}{ Crustaceans } \\
\hline $\mathrm{S}$ & 0.36 & 0.698 & 1,159 & 6.35 & $0.003 * *$ & 1,159 & 1.13 & 0.301 & 1,159 \\
\hline $\mathrm{N}$ & 0.47 & 0.694 & 1,159 & 6.99 & $>0.01 * *$ & 1,159 & 1.03 & 0.354 & 1,159 \\
\hline$H^{\prime}$ & 0.32 & 0.617 & 1,159 & 10.54 & $0.001 * *$ & 1,159 & 0.34 & 0.601 & 1,159 \\
\hline $\mathrm{J}$ ' & 0.15 & 0.783 & 1,159 & 10.66 & $>0.01 * *$ & 1,159 & 0.43 & 0.536 & 1,159 \\
\hline$\Delta^{+}$ & 0.03 & 0.895 & 1,159 & 11.67 & $>0.01 * *$ & 1,159 & 0.22 & 0.683 & 1,159 \\
\hline$\Lambda^{+}$ & 0.83 & 0.385 & 1,159 & 10.57 & $>0.01 * *$ & 1,159 & 0.83 & 0.391 & 1,159 \\
\hline \multicolumn{10}{|c|}{ Echinoderms } \\
\hline $\mathrm{S}$ & 1.27 & 0.229 & 1,159 & 7.14 & $0.004 * *$ & 1,159 & 7.25 & $0.004 * *$ & 1,159 \\
\hline $\mathrm{N}$ & 3.02 & 0.051 & 1,159 & 4.94 & $0.012 * *$ & 1,159 & 7.36 & $0.002 * *$ & 1,159 \\
\hline$H^{\prime}$ & 11.23 & $>0.01 * *$ & 1,159 & 0.68 & 0.423 & 1,159 & 22.31 & $>0.01 * *$ & 1,159 \\
\hline J' & 7.56 & $0.002 * *$ & 1,159 & 5.56 & $0.011 * *$ & 1,159 & 14.54 & $>0.01 * *$ & 1,159 \\
\hline$\Delta^{+}$ & 1.50 & 0.192 & 1,159 & 6.39 & $0.007 * *$ & 1,159 & 6.24 & $0.011 * *$ & 1,159 \\
\hline$\Lambda^{+}$ & 7.79 & $0.003 * *$ & 1,159 & 7.83 & $0.003 * *$ & 1,159 & 5.46 & $0.012 * *$ & 1,159 \\
\hline \multicolumn{10}{|l|}{ Fish } \\
\hline $\mathrm{S}$ & 0.88 & 0.361 & 1,159 & 6.17 & $0.007 * *$ & 1,159 & 3.32 & 0.968 & 1,159 \\
\hline $\mathrm{N}$ & 1.59 & 0.168 & 1,159 & 6.31 & $0.002 * *$ & 1,159 & 3.27 & 0.993 & 1,159 \\
\hline$H^{\prime}$ & 1.69 & 0.190 & 1,159 & 1.37 & 0.233 & 1,159 & 3.56 & 0.883 & 1,159 \\
\hline J' & 2.18 & 0.065 & 1,159 & 1.17 & 0.294 & 1,159 & 4.30 & 0.961 & 1,159 \\
\hline$\Delta^{+}$ & 1.77 & 0.267 & 1,159 & 1.63 & 0.166 & 1,159 & 4.74 & 0.997 & 1,159 \\
\hline$\Lambda^{+}$ & 0.26 & 0.893 & 1,159 & 2.20 & 0.073 & 1,159 & 3.97 & 0.998 & 1,159 \\
\hline
\end{tabular}




\section{Results}

We identified 204 species from the collected and observed samples: macroalgae (22 species), molluscs (55), crustaceans (78), echinoderms (11), and fish (38). For macroalgae, the most abundant families were Dictyotaceae (5 species) and Corallinaceae (4 species). Among molluscs, the best represented were Conidae (8 species), Collumbellidae (6 species), and Mytilidae (6 species). Among crustaceans, the best represented were Porcellanidae (12 species), Xanthidae ( 7 species), and Alpheidae (3 species). Among echinoderms, each of the five families presented two species, and for fishes, the most represented were Labridae (6 species) and Pomacentridae ( 5 species). Appendix 1 shows all taxa at each site and season.

According to the analysis of species accumulation curves, sampling accounted for over 80 percent of the expected species richness. Based on the Jacknife 1 and Bootstrap tests, the species accumulation curves reached a maximum value of 24 and 23 species for macroalgae; while for molluscs it was 84 and 67; for crustaceans 102 and 89; for echinoderms 12 and 11, and for fish 50 and 46 species.

Results of the PERMANOVA test indicated that the community structure of macroalgae, macroinvertebrates, and fishes tend to be relatively similar between sites (Table $1)$; and only the molluscs $(N)$ and the echinoderms ( $H^{\prime}, J^{\prime}$ and $\Lambda^{+}$) showed significant statistical differences (Table 1). Interestingly, for macroalgae and echinoderms the highest $\mathrm{S}, H^{\prime}, J^{\prime}$, and $\Delta^{+}$occurred at Islas Marietas, while for the remaining macroinvertebrates (molluscs and crustaceans), all indices where higher at Tehuamixtle (Figs. 2 and 3). Finally, for fish S, $N, \Delta^{+}$and $\Lambda^{+}$were higher at the island (Marietas), while the remaining indices ( $H^{\prime}$ and $\left.J^{\prime}\right)$ were higher at the coastal site (Table 1, Figs. 2 and 3).

The assemblages of macroalgae, macroinvertebrates, and fishes were different between seasons. For macroalgae, all indices were statistically higher in summer and the same trend was observed for $\mathrm{S}, \Delta^{+}$and $\Lambda^{+}$in molluscs. In the case of crustaceans and echinoderms all indices were statistically different between seasons, but higher diversity was registered during the winter. The fish group showed statistical differences only in $\mathrm{S}$ and $N$, with the higher values during the summer (Table 1; Figs. 2 and 3). Finally, the echinoderms were the only group where significant differences in $\mathrm{H}^{\prime}$ and $\Delta^{+}$were found between sites and season (Table 1).

The NMDS showed that community structure was relatively homogeneous for each group when comparing sites, as the values dispersion showed no particular pattern. In contrast, all assemblages were different between seasons, except for echinoderms (Fig. 4). According to the SIMPER analysis, the species that contribute the most to the dissimilarity between sites and seasons are the macroalgae Bossiella californica and Amphiroa beauvoisii, the molluscs Lithophaga aristata and Septifer zeteki, the crustaceans Acantholobulus mirafloresensis and Pimochirus sp., the echinoderms Ophiocnida hispida, Ophiocoma alexandri, and Ophiotrix spiculata, and the fishes Halichoeres dispilus
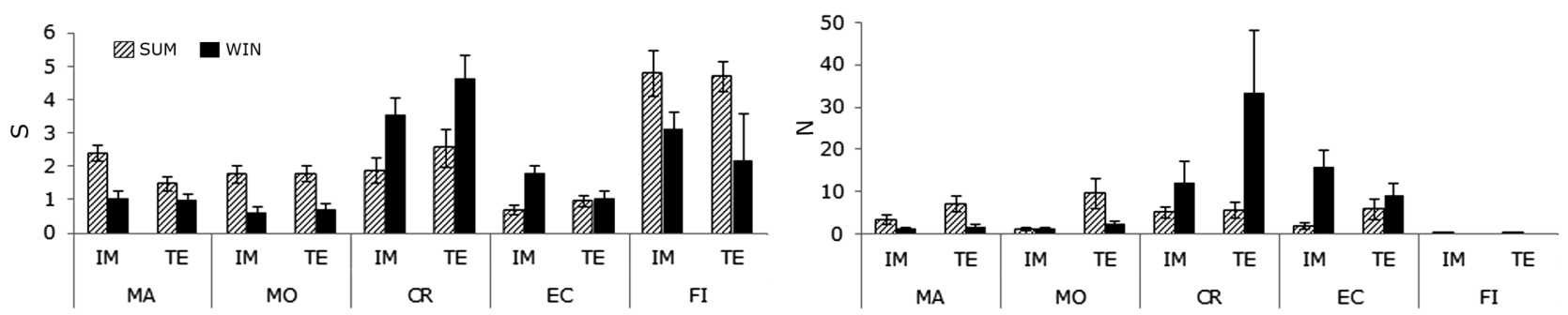

Figure 2. Mean ( $\pm \mathrm{SE}$ ) of species richness (S), relative species abundance ( $\mathrm{N}$ ), and Shannon Index ( $\mathrm{H}^{\prime}$ ) at 2 sites during 2 seasons in the southeastern Gulf of California. IM: Islas Marietas, TE: Tehuamixtle / Promedio ( \pm EE) de riqueza de especies (S), abundancia relativa de especies $(\mathrm{N})$ e índice de Shannon $\left(\mathrm{H}^{\prime}\right)$ en 2 sitios durante 2 estaciones en el sur del Golfo de California. IM: Islas Marietas, TE: Tehuamixtle

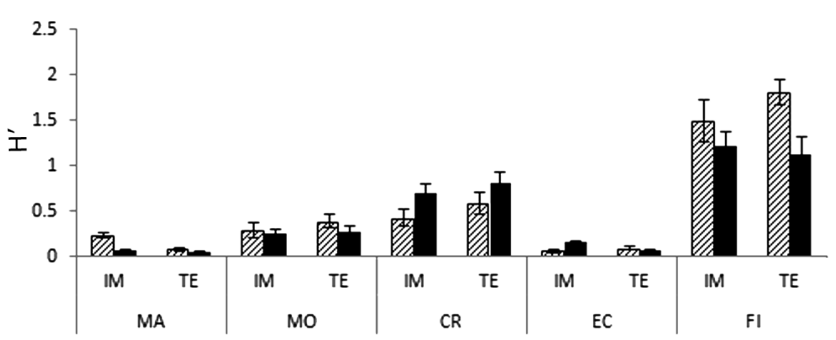




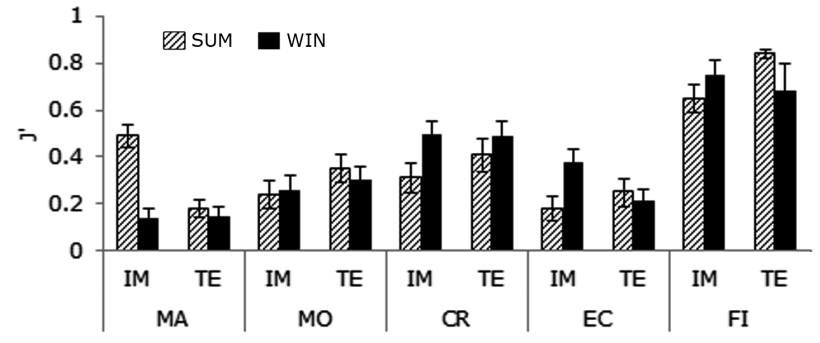

Figure 3. Mean ( $\pm S E$ ) of Pielou's Index $\left(J^{\prime}\right)$, taxonomic distinctness index $\left(\Delta^{+}\right)$, and variation in the taxonomic distinctness $\left(\Lambda^{+}\right)$at 2 sites during 2 seasons in the southeastern Gulf of California. IM: Islas Marietas, TE: Tehuamixtle / Promedio ( $\pm \mathrm{EE}$ ) del índice de Pielou (J'), índice de distintividad taxonómica, $\left(\Delta^{+}\right)$, y variación del índice de distintividad taxonómica $\left(\Lambda^{+}\right)$en 2 sitios durante 2 estaciones en el sur del Golfo de California. IM: Islas Marietas, TE: Tehuamixtle
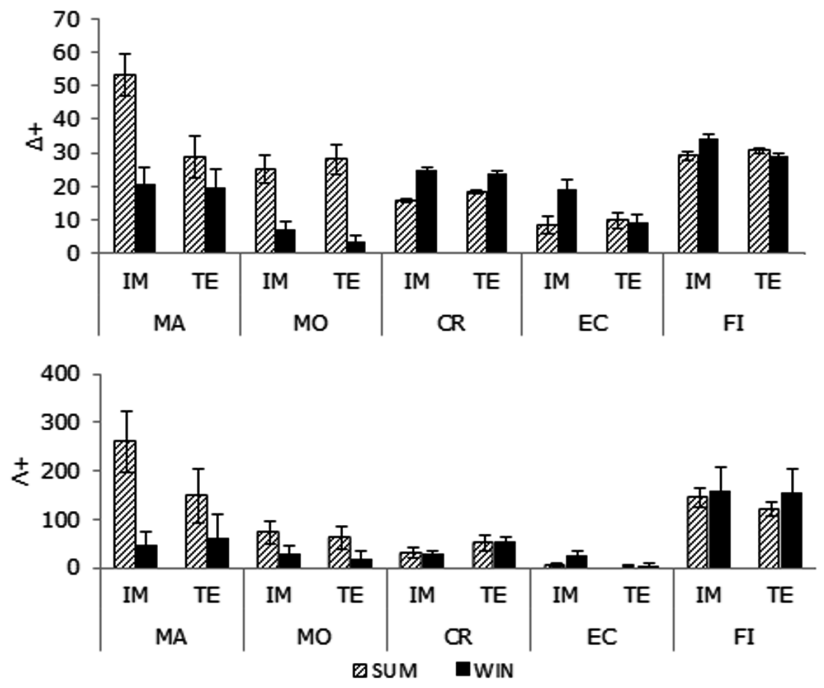
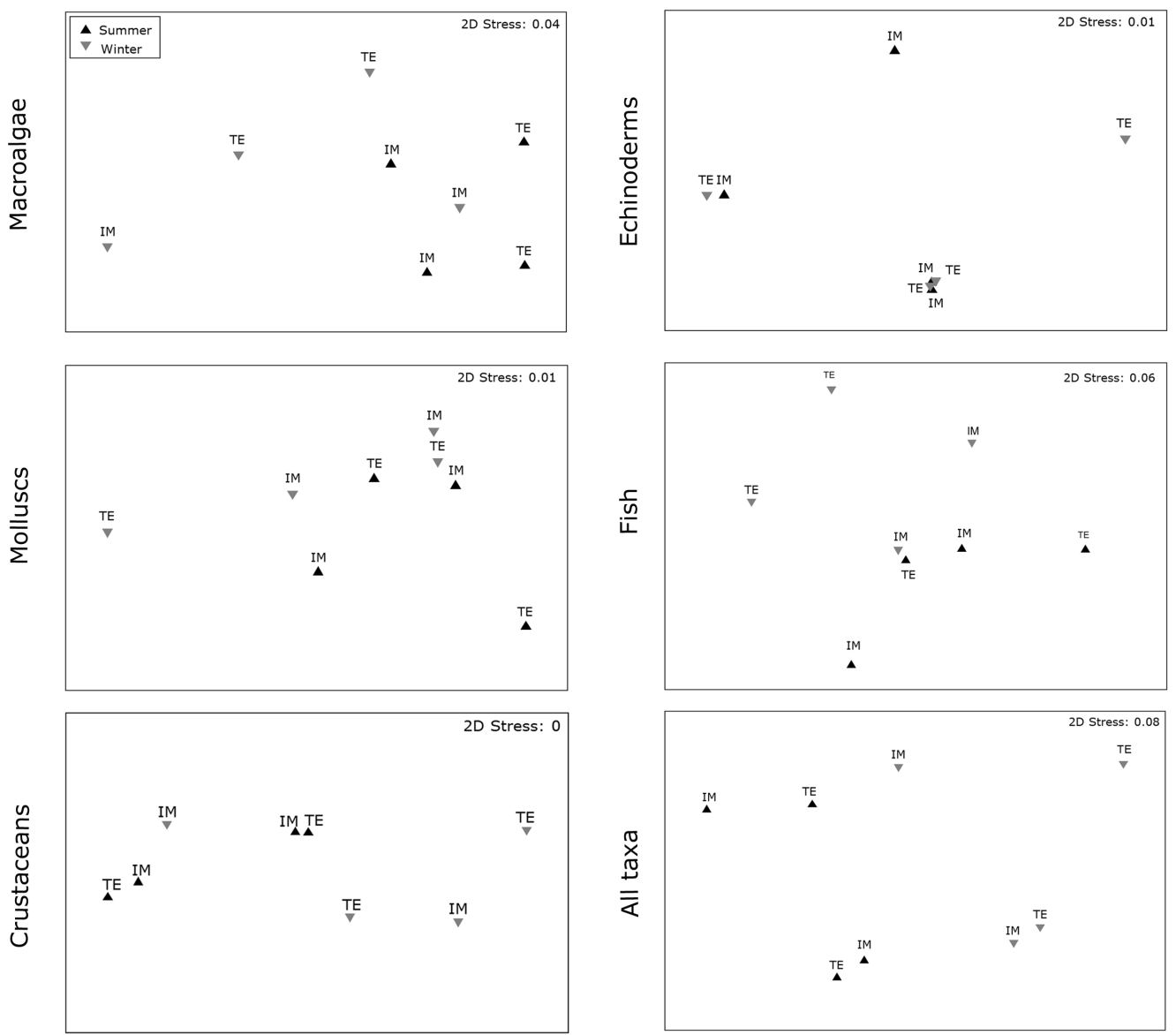

Figure 4. Nonmetric multidimensional scaling plot for taxa at 2 sites and 2 seasons in the southeast of the Gulf of California. IM: Islas Marietas; TE: Tehuamixtle. Black triangles: summer, gray triangles: winter / Escala multidimensional no métrica por taxa en 2 sitios en 2 estaciones en el sur del Golfo de California. IM: Islas Marietas; TE: Tehuamixtle. Triángulos negros: verano, triángulos gris: invierno 
and Thalassoma lucasanum (Table 2). Together, the NMDS and the dominant species depicted in the SIMPER analyses confirmed that faunal composition between sites is similar (Table 2, Fig. 4).

\section{Discussion}

Two general picture emerge from the analysis in this tropical-temperate transitional zone in the Pacific waters off central Mexico. Spatially, there is a high similarity among the assemblages of most taxa in both sites, and on the contrary, a significant seasonal difference in composition and assemblage's descriptor between sites. The overall spatial similarity entails to consider this region as homogeneous from a biological community perspective (Caro et al. 2010). This indicates that the environmental factors controlling both areas are similar, that there may be high connectivity among areas, and that they share the regional species pool (Shackell et al. 2012). In the other hand, seasonal differences seem to be a reflex of the recruitment strategies of each taxon. Thus, macroalgae, molluscs and fishes were more diverse in summer, and crustaceans and echinoderms in winter. A similar trend, that is higher diversity during warmer periods, had been reported for algae and fishes for the region (Mateo-Cid \& Mendoza-González 1991, 1992; Mendoza-González et al. 1994, Aburto-Oropeza \& Balart 2001, Alvarez-Filip et al. 2007, Galvan-Villa et al. 2011, López-Pérez et al. 2012,). Reyes-Bonilla and Alvarez-Filip (2008) found the same pattern in reef fishes based on taxonomic distinctness. For molluscs, the differences in richness and taxonomic distinctness between seasons can be due to local recruitment, as suggested by Olabarría et al. (2001), since both indices reach higher values in the warm season (spring-summer), when the reproductive peak for most bivalve species in the area occur (Osuna et al. 2008).

Table 2. Summary of results from SIM PER tests, showing the relative abundance values for taxa between sites and seasons with the contribution of each taxa to the dissimilarity / Resumen de los resultados del SIMPER, mostrando los valores de abundancia relativa para cada taxa entre sitios y estaciones con la contribución de disimilaridad para cada taxa

\begin{tabular}{|c|c|c|c|c|c|c|c|c|c|c|c|c|}
\hline Taxa & IM & TE & $\begin{array}{l}\text { Av. } \\
\text { Diss }\end{array}$ & $\begin{array}{l}\text { Diss } \\
\text { (SD) }\end{array}$ & $\begin{array}{c}\% \\
\text { Contrib }\end{array}$ & $\underset{\%}{\text { Cum }}$ & Summer & Winter & $\begin{array}{l}\text { Av. } \\
\text { Diss }\end{array}$ & $\begin{array}{l}\text { Diss } \\
\text { (SD) }\end{array}$ & $\begin{array}{c}\% \\
\text { Contrib }\end{array}$ & $\begin{array}{c}\text { Cum } \\
\%\end{array}$ \\
\hline \multicolumn{13}{|l|}{ Macroalgae } \\
\hline Bossiella californica & 0.68 & 0.75 & 25.03 & 0.70 & 25.93 & 25.93 & 1.10 & 0.33 & 26.77 & 0.73 & 27.58 & 27.58 \\
\hline Amphiroa beauvoisii & 0.19 & 0.09 & 6.50 & 0.34 & 6.74 & 32.67 & 0.18 & 0.10 & 5.83 & 0.34 & 6.01 & 33.59 \\
\hline Padina caulescens & 0.01 & 0.39 & 6.46 & 0.31 & 6.70 & 39.36 & - & 0.40 & 5.55 & 0.29 & 5.72 & 39.31 \\
\hline Padina mexicana & 0.09 & 0.11 & 6.34 & 0.34 & 6.57 & 45.93 & 0.08 & 0.12 & 6.77 & 0.35 & 6.97 & 46.28 \\
\hline Dictyota dichotoma var. intricata & 0.11 & - & 6.12 & 0.34 & 6.34 & 52.27 & 0.11 & - & 7.30 & 0.37 & 7.52 & 53.8 \\
\hline TOTAL & 1.08 & 1.34 & & & 52.28 & & 1.47 & 0.83 & & & 53.8 & \\
\hline \multicolumn{13}{|l|}{ Molluscs } \\
\hline Lithophaga aristata & 0.88 & 0.74 & 26.68 & 0.82 & 27.82 & 27.82 & 0.85 & 0.76 & 26.68 & 0.83 & 27.70 & 27.70 \\
\hline Septifer zeteki & 0.24 & 0.33 & 12.23 & 0.50 & 12.75 & 40.58 & 0.35 & 0.21 & 12.02 & 0.50 & 12.48 & 40.18 \\
\hline Hipponix imbricatus & - & 3.04 & 8.47 & 0.35 & 8.84 & 49.41 & 3.04 & - & 8.51 & 0.34 & 8.84 & 49.01 \\
\hline TOTAL & 1.12 & 4.11 & & & 49.41 & & 4.24 & 0.97 & & & 49.02 & \\
\hline \multicolumn{13}{|l|}{ Crustaceans } \\
\hline Acantholobulus mirafloresensis & 4.05 & 4.41 & 17.39 & 0.67 & 18.01 & 18.01 & 1.39 & 7.08 & 15.88 & 0.64 & 16.42 & 16.42 \\
\hline Phimochirus sp. & 4.05 & 3.45 & 10.66 & 0.49 & 11.04 & 29.04 & 0.03 & 7.48 & 11.93 & 0.52 & 12.33 & 28.75 \\
\hline Pilumnus pygmaeus & 0.53 & 20.81 & 8.07 & 0.40 & 8.35 & 37.40 & 0.01 & 21.33 & 8.92 & 0.43 & 9.22 & 37.97 \\
\hline Petrolisthes manimaculis & 0.29 & 0.75 & 6.89 & 0.47 & 7.13 & 44.53 & 0.21 & 0.83 & 7.34 & 0.47 & 7.59 & 52.65 \\
\hline Pisidia magdalenensis & 2.10 & 1.06 & 5.70 & 0.42 & 6.43 & 50.96 & 0.11 & 3.05 & 6.86 & 0.43 & 7.09 & 52.65 \\
\hline TOTAL & 10.49 & 26.07 & & & 50.96 & & 1.75 & 39.77 & & & 52.65 & \\
\hline \multicolumn{13}{|l|}{ Echinoderms } \\
\hline Ophiocnida hispida & 6.74 & 5.56 & 54.71 & 1.56 & 61.14 & 61.14 & 1.99 & 10.31 & 56.78 & 1.63 & 62.54 & 62.54 \\
\hline TOTAL & 6.74 & 5.56 & & & 61.14 & & 1.99 & 10.31 & & & 62.54 & \\
\hline \multicolumn{13}{|l|}{ Fish } \\
\hline Halichoeres dispilus & 15.73 & 5.93 & 20.22 & 0.98 & 24.57 & 24.57 & 18.58 & 5.65 & 21.14 & 1.09 & 25.86 & 25.86 \\
\hline Thalassoma lucasanum & 8.53 & 4.57 & 10.92 & 0.82 & 13.28 & 37.85 & 11.75 & 3.00 & 10.68 & 1.04 & 13.06 & 38.92 \\
\hline Stegastes flavilatus & 2.93 & 5.21 & 7.31 & 0.92 & 8.89 & 46.74 & 7.25 & 1.76 & 7.97 & 1.12 & 9.75 & 48.67 \\
\hline TOTAL & 27.19 & 11.14 & & & 46.74 & & 37.58 & 10.41 & & & 48.67 & \\
\hline
\end{tabular}


The cases of crustaceans and echinoderms contrast, in first instance, with the previous reports. Ramírez-Luna et al. (2002) and Zamorano \& Leyte-Morales (2005) mention that for Huatulco, Mexico, located in the southern part of the Mexican Pacific $\left(16^{\circ} \mathrm{N}\right)$, the crustaceans and echinoderms show higher species richness, $H^{\prime}$, and abundance during the winter, a pattern that is similar to our results. However, Hernández et al. (2009) reported no seasonality in the diversity of reef-associated invertebrates in Bahía de $\mathrm{La} \mathrm{Paz}\left(24^{\circ} \mathrm{N}\right)$. We suggest there is a latitudinal pattern of seasonal change among echinoderms and crustaceans along the coasts of the Mexican Pacific. Future observations toward the south and north may confirm our hypothesis.

\section{ACKNOWLEDGMENTS}

Thanks to Alejandra Mazariegos Villarreal at CIBNOR, Patricia Salazar and Adrián Maldonado at ITBB, and Carmen Esqueda, Norma Arcelia Barrientos and Cristian Galván at Laboratorio de Ecosistemas Marinos y Acuacultura, Departamento de Ecología, Universidad de Guadalajara. Margarita Hermoso Salazar, Manuel Ayón Parente, Michel Hendrickx, and César Ramón Meza Arreola provided technical support. Ira Fogel from CIBNOR provided editorial services and advice. Permiso de Pesca de Fomento SAGARPA DGOPA.00543.020211.0170. Funding was provided by the Centro de Investigaciones Biológicas del Noroeste (CIB EP19), Dirección General de Educación Superior Tecnológica (Project 3333.10-P), and Consejo Nacional de Ciencia y Tecnología (CONACYT Grants 25992 and 179327). V.C.GH. is a recipient of a doctoral fellowship (CONACYT 95021).

\section{LITERATURE CITED}

Aburto-Oropeza O \& EF Balart. 2001. Community structure of reef fish in several habitats of a rocky reef in the Gulf of California. Marine Ecology 22(4): 283-305.

Alvarez-Filip L, H Reyes-Bonilla \& LE Calderon-Aguilera. 2007. Community structure of fishes in Cabo Pulmo Reef, Gulf of California. Marine Ecology 27: 253-262.

Anderson MJ. 2001. A new method for non-parametric multivariate analysis of variance. Austral Ecology 26: 32-46.

Anderson RJ, JJ Bolton, AJ Smit \& DDS Neto 2012. The seaweeds of Angola: The transition between tropical and temperate marine floras on the west coast of southern Africa, African Journal of Marine Science 34(1): 1-13.

Badán A. 1997. La corriente costera de Costa Rica en el Pacífico Mexicano. In: Lavín MF (ed). Contribuciones a la oceanografía física en México. Monografía 3: 99-112. Unión Geofísica Mexicana, México.
Briggs J. 1974. Marine zoogeography, 475 pp. McGraw-Hill, New York.

Caro A, S Navarrete \& J Castilla. 2010. Ecological convergence in a rocky intertidal shore metacommunity despite high spatial variability in recruitment regimes. Proceedings of the National Academy of Sciences 107: 18528-18532.

Casas-Valdez M, R Núñez-López, M Cruz-Ayala, I SánchezRodríguez, R Vázquez-Borja \& G López. 2000. Biodiversity and biogeographic affinities of the algal flora of Baja California Sur: A synthesis of the literature. In: Munawar M, S Lawrence, I Munawar \& D Malley (eds). Aquatic ecosystems of Mexico: Status and scope, pp. 273282. Econovision World Monograph Series, Backhuys Publishers, Leiden.

Castro-Aguirre JL, AF González-Acosta, J de la CruzAgüero \& R Moncayo-Estrada. 2006. Ictiofauna marinacostera del Pacífico central mexicano: análisis preliminar de su riqueza y relaciones biogeográficas. En: Jímenez-Quiróz MC \& E Espino-Barr (eds). Los recursos pesqueros y acuícolas de Jalisco, Colima y Michoacán, pp. 149-208. Instituto Nacional de la Pesca, CRIP-Manzanillo, SAGARPA, México.

Chavez-Comparán JC, E Espino-Barr \& B Lara-Chávez. 2006. Peces de arrecifes rocosos de las Bahías de Manzanillo y Santiago Colima, México. En: Jímenez-Quiróz MC \& E Espino-Barr (eds). Los recursos pesqueros y acuícolas de Jalisco, Colima y Michoacán, pp. 174-179. Instituto Nacional de la Pesca, CRIP-Manzanillo, SAGARPA, México.

Clarke K \& R Gorley. 2006. PRIMER v6: User Manual/ Tutorial. PRIMER-E, Ivybridge.

Clarke K \& R Warwick. 1998. Quantifying structural redundancy in ecology communities. Oecologia 113: 278-289.

Clarke K \& R Warwick. 2001. A further biodiversity index applicable to species lists: variation in taxonomic distinctness. Marine Ecology Progress Series 216: 265-278.

CNA. 2012. Atlas del agua en México, 2012, 32 pp. Secretaria de Medio Ambiente y Recursos Naturales, Comisión Nacional del Agua, México.

CONANP. 2007. Programa de Conservación y Manejo Parque Nacional Islas Marietas. 2007, 155 pp. Secretaria de Medio Ambiente y Recursos Naturales, México.

Dayton PK. 1971. Competition, disturbance, and community organization: The provision and subsequent utilization of space in a rocky intertidal community. Ecological Monographs 41: 351-389.

Dayton PK \& MJ Tegner. 1984. Catastrophic storms, El Niño, and patch stability in a southern California kelp community. Science 224: 283-285.

Duffy J \& J Stachowicz. 2006. Why biodiversity is important to oceanography: potential roles of genetic, species, and trophic diversity in pelagic ecosystem processes. Marine Ecology Progress Series 311: 179-189. 
Enciso-Padilla I \& E Serviere-Zaragoza. 2006. Macroalgas del límite norte del Pacífico tropical mexicano. En: JímenezQuiróz MC \& E Espino-Barr (eds). Los recursos pesqueros y acuícolas de Jalisco, Colima y Michoacán, pp. 299-310. Instituto Nacional de la Pesca, CRIP-Manzanillo, SAGARPA, México.

Galván-Villa CM, E López-Uriarte \& JL Arreola-Robles. 2011. Diversidad, estructura y variación temporal del ensamble de peces asociados al arrecife coralino de playa Mora, bahía de Tenacatita, México. Hidrobiología 21: 135146.

Gasca R. 2009. Hyperiid amphipods (Crustacea: Peracarida) in Mexican waters of the Pacific Ocean. Pacific Science 63: 83-95.

Hernández-Herrera R, S Ibarra-Obando \& M MoraNavarro. 2005. Macroalgae community structure in southern coast of Jalisco, México. Scientia-CUCBA 7(2): 139-154.

Hernández L, EF Balart \& H Reyes-Bonilla. 2009. Checklist of reef decapod crustaceans (Crustacea: Decapoda) in the southern Gulf of California, Mexico. Zootaxa 2119: 39-50.

Kaehler S \& GA Williams. 1998. Early development of algal assemblages under different regimes of physical and biotic factors on a seasonal tropical rocky shore. Marine Ecology Progress Series 172: 61-71.

López-Pérez RA, LE Calderon-Aguilera, RC ZepetaVilchis, IL Pérez-Maldonado \& AM López-Ortiz. 2012. Species composition, habitat configuration and seasonal changes of coral reef fish assemblages in western Mexico. Journal of Applied Ichthyology 29: 437-448.

Mateo-Cid L \& A Mendoza-González. 1991. Algas marinas bentónicas de la costa del estado de Colima, México. Acta Botánica Mexicana 13: 9-30.

Mateo-Cid L \& A Mendoza-González. 1992. Algas marinas bentónicas de la Costa Sur de Nayarit, México. Acta Botánica Mexicana 20: 13-28.

Mendoza-González AC, LE Mateo-Cid \& L HuertaMúzquiz. 1994. Algas marinas bentónicas de Mazatlán, Sinaloa, México. Acta Botánica Mexicana 27: 99-115.

Menge BA. 1976. Organization of the New England rocky intertidal community: role of predation, competition and environmental heterogeneity. Ecological Monographs 46: 355-393.

Montgomery D. 1991. Design and analysis of experiments, 650 pp. John Wiley \& Sons, New York.

Morrone JJ. 2009. Evolutionary biogeography: An integrative approach with case studies. 301 pp. Columbia University Press, New York.

Mouillot D, NAJ Graham, S Villéger, NWH Mason \& DR Bellwood. 2013. A functional approach reveals community responses to disturbances. Trends in Ecology \& Evolution 28(3): 167-177.
Nelson J. 2006. Fishes of the world, 601 pp. John Wiley \& Sons, Hoboken.

Olabarría C, J Caraballo \& C Vega. 2001. Cambios espaciotemporales en la estructura trófica de asociaciones de moluscos del intermareal rocoso en un sustrato tropical. Ciencias Marinas 27: 235-254.

Osuna LS, PA Garzón, JIO López \& D Voltolina. 2008. Moluscos bivalvos de la Bahía de Altata y Estero Tetuán, Sinaloa. En: Corrales VA \& J Milán (coord). La investigación científica, tecnológica y social en la UAS, pp. 131-133. Ed. Universidad Autónoma de Sinaloa, Mazatlán.

Ramírez-Luna S, G De la Cruz-Aguero \& N BarrientosLuján. 2002. Variación espacio temporal de Porcellanidae, Majoidea y Xanthoidea asociados a corales Pocillopora en bahías de Huatulco, México. En: Hendrickx ME (ed). Contributions to the study of East Pacific Crustaceans, Volume 1: 233-254. Instituto de Ciencias del Mar y Limnología, Universidad Nacional Autónoma de México, Mazatlán, Sinaloa.

Reyes-Bonilla H \& L Alvarez-Filip. 2008. Long-term changes in taxonomic distinctness and trophic structure of reef fishes at Cabo Pulmo Reef, Gulf of California. In: Bernhardt RB (ed). Proceedings of the 11 th International Coral Reef Symposium, pp. 790-794. Fort Lauderdale, Florida.

Reynolds R, N Rayner, T Smith, D Stokes \& W Wang. 2012. An improved in situ and satellite SST analysis for climate. Journal of Climate 16: 1609-1625. <ftp:// ftp.cdc.noaa.gov/Datasets/noaa.oisst.v2/sst.mnmean.nc>.

Ríos-Jara E, M Perez-Peña, E López-Uriarte, I EncisoPadilla \& E Juárez-Carrillo. 2006. Biodiversidad de moluscos marinos de la costa de Jalisco y Colima, con anotaciones sobre su aprovechamiento en la región. En: Jímenez-Quiróz MC \& E Espino-Barr (eds). Los recursos pesqueros y acuícolas de Jalisco, Colima y Michoacán, pp. 103-120. Instituto Nacional de la Pesca, CRIP-Manzanillo, SAGARPA, México.

Ríos-Jara E, CM Galván-Villa \& FA Solís-Marín. 2008. Equinodermos del Parque Nacional Isla Isabel, Nayarit, México. Revista Mexicana de Biodiversidad 79: 131-141.

Ríos-Jara E, C Galván-Villa, F Rodríguez-Zaragoza, E López-Uriarte, D Bastida-Izaguirre \& F Solís-Marín. 2013. Los equinodermos (Echinodermata) de bahía Chamela, Jalisco, México. Revista Mexicana de Biodiversidad. 84: 263-279.

Robertson DR \& GR Allen. 2008. Shorefishes of the tropical eastern Pacific: an information system. Versión 2.0 (2008). Smithsonian Tropical Research Institute, Balboa. [DVD]

Ruggiero A \& E Ezcurra. 2003. Regiones y transiciones biogeográficas: Complementariedad de los análisis en biogeografía histórica y ecológica. En: Morrone JJ \& J Llorente (eds). Una perspectiva latinoamericana de la biogeografía, pp. 141-154. Facultad de Ciencias, Universidad Nacional Autónoma de México, México. 
Sarukhan J. 2009. Capital natural de México. Volumen II: Estado de conservación y tendencias de cambio, 817 pp. Comisión Nacional para el Conocimiento y Uso de la Biodiversidad, México.

Shackell N, J Fisher, K Frank \& P Lawton. 2012. Spatial scale of similarity as an indicator of metacommunity stability in exploited marine systems. Ecological Applications 22: 336-348.

Somerfield PJ, SJ Cochrane, S Dahle \& TH Pearson. 2006. Free-living nematodes and macrobenthos in a high-latitude glacial fjord. Journal of Experimental Marine Biology and Ecology 330: 284-296.

Somerfield PJ, KR Clarke, RM Warwick \& NK Dulvy. 2008. Average functional distinctness as a measure of the composition of assemblages. ICES Journal of Marine Science 65: 1462-1468.

Underwood AJ. 2000. Experimental ecology of rocky intertidal habitats: what are we learning? Journal of Experimental Marine Biology and Ecology 250: 51-76.
Underwood AJ \& MG Chapman. 1998. Variation in algal assemblages on wave exposed rocky shores in New South Wales. Marine Freshwater Research 49: 241-254.

Wootom JT. 1993. Indirect effects and habitat use in an intertidal community: interaction chains and interaction modifications. American Naturalist 141: 71-89.

Zajac RM, RS Lewis, LJ Poppe, DC Twichell, J Vozarik \& ML DiGiacomo-Cohen. 2003. Responses of infaunal populations to benthoscape structure and the potential importance of transition zones. Limnology and Oceanography 48(2): 829-842.

Zamorano P \& GE Leyte-Morales. 2005. Cambios en la diversidad de equinodermos asociados al arrecife coralino en La Entrega, Oaxaca, México. Ciencia y Mar 27: 19-28.

Zar J. 1999. Biostatistical analysis, 662 pp. Prentice Hall, Upper Saddle River. 
Appendix 1. Abundance of macroalgae $\left(\mathrm{g} / 0.0625 \mathrm{~m}^{2}\right)$, molluscs, crustaceans, echinoderms (org/0.0625 $\left.\mathrm{m}^{2}\right)$ and fish (fish/10 $\left.\mathrm{m}^{2}\right) \mathrm{species} \mathrm{in} \mathrm{the}$ southern Gulf of California (IM = Islas Marietas, TE= Tehuamixtle) / Abundancia de macroalgas (g 0,0625 m2), moluscos, crustáceos, equinodermos (org $/ 0,0625 \mathrm{~m}^{2}$ ) y peces (fish/10 $\mathrm{m}^{2}$ ) en el sur del Golfo de California (IM=Islas Marietas, TE= Tehuamixtle)

\begin{tabular}{|c|c|c|c|c|c|c|}
\hline \multirow{2}{*}{ Classe/Orden } & \multirow{2}{*}{ Family } & \multirow{2}{*}{ Specie } & \multicolumn{2}{|c|}{ Sites } & \multicolumn{2}{|c|}{ Seasons } \\
\hline & & & Im & $\mathrm{Te}$ & Summer & Winter \\
\hline \multicolumn{7}{|l|}{ MACROALGAE } \\
\hline \multicolumn{7}{|l|}{ Ulvophyceae } \\
\hline Ulvales & Ulvaceae & Ulva californica Wille, 1899 & - & $<0.010$ & $<0.001$ & - \\
\hline \multirow[t]{2}{*}{ Cladophorales } & Cladophoraceae & Chaetomorpha linum (O.F. Müller) Kützing, 1845 & 0.003 & - & 0.003 & - \\
\hline & & Rhizoclonium riparium (Roth) Harvey, 1849 & - & 0.013 & - & 0.013 \\
\hline \multirow[t]{3}{*}{ Bryopsidales } & Codiaceae & Codium brandegeei Setchel \& N.L. Gardner, 1924 & - & $<0.01$ & - & $<0.001$ \\
\hline & & Codium simulans Setchel \& N.L. Gardner, 1924 & - & 0.008 & - & 0.009 \\
\hline & Halimedaceae & Halimeda discoidea Decaisne, 1842 & 0.017 & - & 0.002 & 0.015 \\
\hline \multicolumn{7}{|l|}{ Phaeophyceae } \\
\hline \multirow[t]{5}{*}{ Dictyotales } & Dictyotaceae & Dictyota dichotoma var. intricata (C. Agardh) Greville, 1830 & 0.111 & 0.001 & 0.112 & - \\
\hline & & Padina caulescens Thivy, 1945 & 0.034 & 0.084 & 0.002 & 0.115 \\
\hline & & Padina crispata Thivy, 1945 & 0.085 & 0.111 & 0.076 & 0.121 \\
\hline & & Padina durvillei Bory Saint-Vincent, 1827 & - & 0.576 & 0.576 & - \\
\hline & & Padina mexicana E.Y. Dawson, 1944 & 0.041 & 0.621 & 0.642 & 0.019 \\
\hline Fucales & Sargassaceae & Sargassum liebmannii J. Agardh ,1847 & - & 1.450 & 1.450 & - \\
\hline \multicolumn{7}{|l|}{ Florideophyceae } \\
\hline Geliadiales & Pterocladiaceae & Pterocladia capillacea (S.G. Gmelin) Bornet, 1876 & 0.063 & 0.059 & 0.121 & - \\
\hline \multirow[t]{4}{*}{ Corallinales } & Corallinaceae & Amphiroa beauvoisii J.V. Lamouroux, 1816 & 0.189 & 0.090 & 0.176 & 0.103 \\
\hline & & Bossiella californica (Decaisne) P.C. Silva, 1957 & 0.682 & 0.747 & 1.102 & 0.327 \\
\hline & & Corallina officinalis var. chilensis (Decaisne) Kützing, 1858 & 0.003 & 0.006 & 0.003 & 0.007 \\
\hline & & Jania tenella (Kützing) Grunow, 1874 & 0.009 & 0.388 & - & 0.398 \\
\hline \multirow[t]{4}{*}{ Rhodymeniales } & Faucheaceae & Gloiocladia conjuncta (Setchel \& N.L. Gardner) R.E. Norris, 1991 & 0.101 & - & 0.101 & - \\
\hline & Rhodymeniaceae & Botryocladia pseudodichotoma (Farlow) Kylin, 1931 & 0.026 & - & - & 0.026 \\
\hline & & Botryocladia uvarioides E.Y. Dawson, 1944 & 0.574 & - & 0.574 & - \\
\hline & Lomentariaceae & Gelidiopsis tenuis Setchel \& N.L. Gardner, 1924 & 0.425 & 0.015 & 0.316 & 0.124 \\
\hline Ceramiales & Rhodomelaceae & Bryothamnion pacificum Taylor, 1945 & - & 0.324 & 0.060 & 0.264 \\
\hline \multicolumn{7}{|l|}{ MOLLUSCS } \\
\hline Aplacophora & & & 0.013 & 0.050 & 0.063 & - \\
\hline Polyplacophora & & & 0.013 & 0.013 & 0.025 & - \\
\hline \multicolumn{7}{|l|}{ Gastropoda } \\
\hline Archaeogastropoda & Fissurellidae & Fissurella nigrocincta Carpenter, 1856 & 0.013 & - & 0.013 & - \\
\hline \multirow[t]{20}{*}{ Neotaenioglossa } & Caliptraeidae & Crucibulum monticulus S.S. Berry, 1969 & 0.025 & 0.050 & 0.075 & - \\
\hline & Turritellidae & Turritella leucostoma Valenciennes, 1832 & 0.013 & - & 0.013 & - \\
\hline & Epitoniidae & Opalia funiculata (Carpenter, 1857) & - & 0.013 & - & 0.013 \\
\hline & Hipponicidae & Hipponix imbricatus Edmonson, 1933 & - & 3.038 & 3.038 & - \\
\hline & Triviidae & Trivia pacifica (Sowerby, 1832) & 0.013 & - & - & 0.013 \\
\hline & Cypraeidae & Cypraea albuginosa Gray, 1825 & 0.013 & - & - & 0.013 \\
\hline & & Cypraea arabicula Lamarck, 1811 & 0.038 & 0.013 & 0.05 & - \\
\hline & & Cypraea isabellamexicana Stearns, 1893 & 0.013 & - & 0.013 & - \\
\hline & Muricidae & Hexaplex regius (Swainson, 1821) & 0.013 & - & 0.013 & - \\
\hline & & Mancinella speciosa (Valenciennes, 1832) & - & 0.050 & 0.05 & - \\
\hline & & Mancinella triangularis (Blainville, 1832) & - & 0.050 & 0.05 & - \\
\hline & Buccinidae & Colubraria sp. & 0.013 & - & - & 0.013 \\
\hline & Columbellidae & Columbella aureomexicana (Howard, 1963) & 0.013 & - & 0.013 & - \\
\hline & & Columbella fuscata Sowerby, 1832 & 0.013 & 0.050 & 0.050 & 0.013 \\
\hline & & Columbella haemastoma Sowerby, 1832 & 0.013 & - & 0.013 & - \\
\hline & & Columbella major (Sowerby, 1832) & 0.013 & - & - & 0.013 \\
\hline & & Columbella sonsonatensis (Mörch, 1860) & - & 0.013 & - & 0.013 \\
\hline & & Columbella sp. (juvenil) Lamarck, 1799 & 0.050 & 0.025 & 0.075 & - \\
\hline & Conidae & Conus archon Broderip, 1833 & - & 0.013 & - & 0.013 \\
\hline & & Conus gladiator Broderip, 1833 & 0.063 & 0.025 & 0.05 & 0.038 \\
\hline
\end{tabular}


Appendix 1. Continued / Continuación

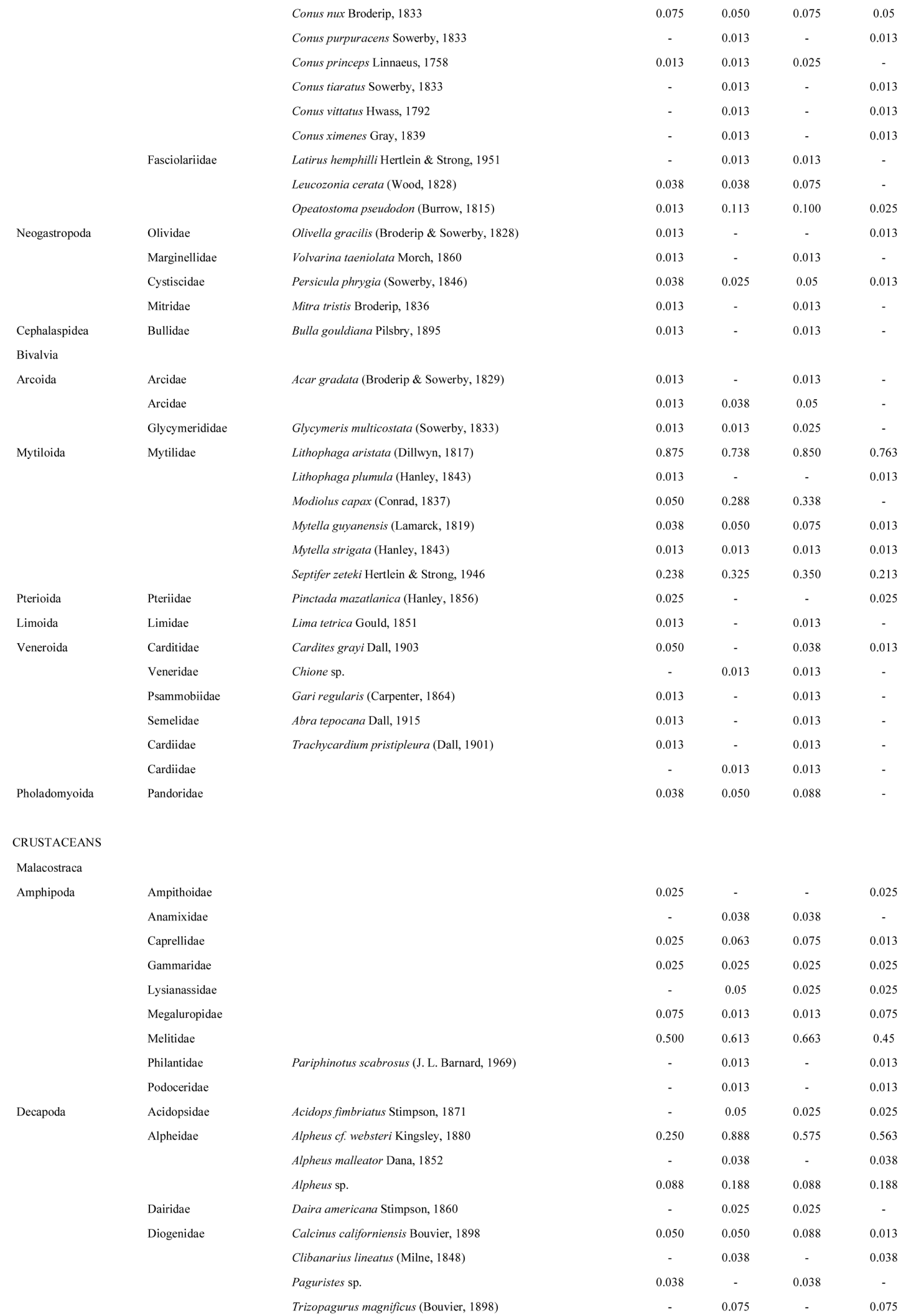


Appendix 1. Continued / Continuación

\begin{tabular}{|c|c|c|c|c|c|c|}
\hline \multirow{4}{*}{\multicolumn{2}{|c|}{ Epialtidae }} & Acanthonyx petiverii $\mathrm{H}$. Milne Edwards, 1834 & 0.013 & 0.175 & 0.013 & 0.175 \\
\hline & & Epialtoides paradigmus Garth, 1958 & - & 0.013 & - & 0.013 \\
\hline & & Epialtus minimus Lockington, 1877 & 0.038 & - & 0.025 & 0.013 \\
\hline & & Pitho sexdentata Bell, 1835 & 0.050 & 0.675 & 0.100 & 0.625 \\
\hline \multirow{5}{*}{\multicolumn{2}{|c|}{ Inachidae }} & Eucinetops rubellutus Rathbun, 1923 & - & 0.013 & 0.013 & - \\
\hline & & Ericerodes casoae Hendricks, 1987 & 0.150 & 0.225 & 0.100 & 0.275 \\
\hline & & Ericerodes veleronis Garth, 1948 & - & 0.125 & - & 0.125 \\
\hline & & Stenorhynchus debilis Smith, 1871 & 0.413 & 0.138 & - & 0.55 \\
\hline & & Inachoides laevis Stimpson, 1860 & 0.025 & 0.025 & - & 0.05 \\
\hline \multirow{3}{*}{\multicolumn{2}{|c|}{ Majidae }} & Microphrys platysoma (Stimpson, 1860) & - & 0.013 & - & 0.013 \\
\hline & & Mithrax pygmaeus Bell, 1835 & - & 0.013 & - & 0.013 \\
\hline & & Teleophrys cristulipes Stimpson, 1860 & 0.038 & - & 0.038 & - \\
\hline & Oziidae & Eupilumnus xantusii Stimpson, 1860 & - & 0.138 & 0.025 & 0.113 \\
\hline & Paguridae & Phimochirus sp. & 4.05 & 3.450 & 0.025 & 7.475 \\
\hline & \multirow[t]{2}{*}{ Palaemonidae } & Brachycarpus biunguiculatus (Lucas, 1846) & - & 0.013 & 0.013 & - \\
\hline & & Pontonia margarita (Smith, 1869) & 0.013 & 0.013 & - & 0.025 \\
\hline & \multirow[t]{2}{*}{ Panopeidae } & Acantholobulus mirafloresensis (Abele \& Kim, 1989) & 4.050 & 4.413 & 1.388 & 7.075 \\
\hline & & Lophoxanthus lamellipes (Stimpson, 1860) & 0.025 & 0.038 & 0.050 & 0.013 \\
\hline & \multirow[t]{3}{*}{ Parthenopidae } & Ochtholambrus stimpsoni (Garth, 1958) & 0.188 & 0.738 & 0.325 & 0.6 \\
\hline & & Parthenope sp. & 0.088 & 0.100 & 0.100 & 0.088 \\
\hline & & Solenolambrus arcuatus Stimpson, 1871 & - & 0.025 & - & 0.025 \\
\hline & \multirow[t]{2}{*}{ Pilumnidae } & Pilumnus pygmaeus Boone, 1927 & 0.525 & 20.813 & 0.013 & 21.325 \\
\hline & & Pilumnus stimpsonii Miers, 1886 & - & 0.013 & - & 0.013 \\
\hline & Pinnotheridae & Calyptraea theresgranti (Glassell, 1933) & 0.063 & - & 0.050 & 0.013 \\
\hline & \multirow[t]{12}{*}{ Porcellanidae } & Clastotoechus diffractus (Haig, 1957) & - & 0.013 & 0.013 & - \\
\hline & & Neopisosoma dohenyi Haig, 1960 & 0.013 & - & - & 0.013 \\
\hline & & Orthochela pumila Glassell, 1936 & - & 0.213 & 0.088 & 0.125 \\
\hline & & Pachycheles biocellatus (Lockington, 1878) & - & 0.063 & 0.050 & 0.013 \\
\hline & & Pachycheles spinidactylus Haig, 1957 & - & 0.013 & - & 0.013 \\
\hline & & Petrolisthes edwardsii (De Saussure, 1853) & - & 0.025 & - & 0.025 \\
\hline & & Petrolisthes haigae Chace, 1962 & - & 0.013 & - & 0.013 \\
\hline & & Petrolisthes hians Nobili, 1901 & 0.013 & 0.025 & 0.025 & 0.013 \\
\hline & & Petrolisthes manimaculis Glassell, 1945 & 0.288 & 0.750 & 0.213 & 0.825 \\
\hline & & Petrolisthes polymitus Glassell, 1937 & 0.038 & - & 0.025 & 0.013 \\
\hline & & Petrolisthes sanfelipensis Glassell, 1936 & 0.200 & - & - & 0.200 \\
\hline & & Pisidia magdalenensis (Glassell, 1936) & 2.100 & 1.063 & 0.113 & 3.050 \\
\hline & Trapeziidae & Trapezia bidentata (Forskål, 1775) & 0.013 & - & 0.013 & - \\
\hline & \multirow[t]{6}{*}{ Xanthidae } & Heteractaea lunata (Lucas, 1844) & - & 0.025 & 0.013 & 0.013 \\
\hline & & Lipaesthesius leeanus Rathbun, 1898 & - & 0.025 & 0.025 & - \\
\hline & & Medaeus spinulifer (Rathbun, 1898) & 0.013 & 0.025 & 0.013 & 0.025 \\
\hline & & Paractaea sulcata Stimpson, 1860 & 0.025 & 0.013 & 0.013 & 0.025 \\
\hline & & Platypodiella rotundata Stimpson, 1860 & - & 0.100 & - & 0.100 \\
\hline & & Xanthodius stimpsoni (A. Milne-Edwards, 1879) & 0.025 & - & - & 0.025 \\
\hline & Xanthidae & & 0.925 & 0.225 & 0.125 & 1.025 \\
\hline \multirow[t]{9}{*}{ Isopoda } & Anthuridae & Anthuridae sp. 1 & 0.025 & - & 0.025 & - \\
\hline & & Anthuridae sp. 2 & - & 0.025 & 0.025 & - \\
\hline & & Anthuridae sp. 3 & - & 0.013 & 0.013 & - \\
\hline & Cirolanidae & Cirolanidae sp. 1 & - & 0.013 & 0.013 & - \\
\hline & & Cirolanidae sp. 2 & 0.125 & 0.025 & 0.138 & 0.013 \\
\hline & & Cirolanidae sp. 3 & 0.063 & 0.038 & 0.025 & 0.075 \\
\hline & & Cirolanidae sp. 4 & 0.013 & 0.063 & 0.038 & 0.038 \\
\hline & Idoteidae & & - & 0.063 & 0.013 & 0.05 \\
\hline & Sphaeromatidae & Paracerceis sculpta (Holmes, 1904) & - & 0.025 & - & 0.025 \\
\hline
\end{tabular}

Vol. 49, № 3, 2014 
Appendix 1. Continued / Continuación

\begin{tabular}{|c|c|c|c|c|c|c|}
\hline Mysida & Mysidae & Mysida sp. & - & 0.013 & - & 0.013 \\
\hline Stomatopoda & Gonodactyloidae & Neogonodactylus stanchi (Schmitt, 1940) & - & 0.013 & - & 0.013 \\
\hline Tanaidacea & Tanaidacea & & - & 0.013 & - & 0.013 \\
\hline \multicolumn{7}{|l|}{ Maxillopoda } \\
\hline \multirow[t]{4}{*}{ Sessilia } & Balanidae & Balanus sp. 1 & - & 0.063 & 0.063 & - \\
\hline & & Balanus sp. 2 & - & 0.338 & 0.300 & 0.038 \\
\hline & & Balanus sp. 3 & 0.013 & 0.013 & 0.013 & 0.013 \\
\hline & & Megabalanus sp. & 0.050 & 0.088 & 0.063 & 0.075 \\
\hline
\end{tabular}

ECHINODERMS

\begin{tabular}{|c|c|c|}
\hline \multicolumn{3}{|l|}{ Echinoidea } \\
\hline Cidaroida & Cidariidae & Eucidaris thouarsii (Valenciennes, 1846) \\
\hline \multicolumn{3}{|l|}{ Ophiuroidea } \\
\hline \multirow[t]{10}{*}{ Ophiurida } & Ophiocomidae & Ophiocoma aethiops Lütken,1859 \\
\hline & & Ophiocoma alexandri Lyman, 1860 \\
\hline & Ophionereididae & Ophionereis annulata (Le Conte, 1851) \\
\hline & & Ophionereis perplexa Ziesenhenne, 1940 \\
\hline & Ophiactidae & Ophiactis savignyi (Müller \& Troschel, 1842) \\
\hline & & Ophiactis simplex (Le Conte, 1851) \\
\hline & Amphiuridae & Amphipholis squamata (Delle Chiaje, 1828) \\
\hline & & Ophiocnida hispida (Le Conte, 1851) \\
\hline & Ophiotrichidae & Ophiothela mirabilis Verrill, 1867 \\
\hline & & Ophiothrix spiculata Le Conte, 1851 \\
\hline
\end{tabular}

$\begin{array}{cccc}0.113 & 0.013 & 0.075 & 0.050 \\ & & & \\ 0.088 & 0.038 & 0.063 & 0.063 \\ 0.713 & 0.275 & 0.225 & 0.763 \\ 0.013 & - & - & 0.013 \\ 0.063 & 0.013 & 0.038 & 0.038 \\ - & 0.050 & 0.038 & 0.013 \\ 0.100 & 0.113 & 0.088 & 0.125 \\ 0.013 & - & - & 0.013 \\ 6.738 & 5.568 & 1.988 & 10.318 \\ 0.525 & 0.875 & 1.188 & 0.213 \\ 0.600 & 0.684 & 0.247 & 1.038\end{array}$

FISH

\begin{tabular}{|c|c|c|}
\hline \multicolumn{3}{|l|}{ Chondrichthyes } \\
\hline \multirow[t]{2}{*}{ Myliobatiformes } & Urotrygonidae & Urobatis concentricus Osburn \& Nichols, 1916 \\
\hline & Dasyatidae & Dasyatis dipterura (Jordan \& Gilbert, 1880) \\
\hline \multicolumn{3}{|l|}{ Actinopterygii } \\
\hline \multirow[t]{3}{*}{ Anguiliformes } & Muraenidae & Echidna nebulosa $(\mathrm{Ahl}, 1789)$ \\
\hline & & Echidna nocturna (Cope, 1872) \\
\hline & & Gymnothorax castaneus (Jordan \& Gilbert, 1883) \\
\hline Beryciformes & Holocentridae & Myripristis leiognathus Valenciennes, 1846 \\
\hline \multirow[t]{19}{*}{ Perciformes } & Serranidae & Cephalopholis panamensis (Steindachner, 1876) \\
\hline & & Epinephelus labriformis (Jenyns, 1840) \\
\hline & & Serranus psittacinus Valenciennes, 1846 \\
\hline & Carangidae & Caranx sexfasciatus Quoy \& Gaimard, 1825 \\
\hline & & Gnathanodon speciosus (Forsskål, 1775) \\
\hline & Lutjanidae & Lutjanus viridis (Valenciennes, 1846) \\
\hline & Haemulidae & Haemulon flaviguttatum Gill, 1862 \\
\hline & Sciaenidae & Pareques cf. viola (Gilbert, 1898) \\
\hline & Mullidae & Mulloidichthys dentatus Gill, 1862 \\
\hline & Chaetodontidae & Chaetodon humeralis Günther, 1860 \\
\hline & & Johnrandallia nigrirostris (Gill, 1862) \\
\hline & Pomacanthidae & Holacanthus passer Valenciennes, 1846 \\
\hline & & Pomacanthus zonipectus (Gill, 1863) \\
\hline & Cirrhitidae & Cirrhitus rivulatus Valenciennes, 1846 \\
\hline & Pomacentridae & Abudefduf troschelii (Gill, 1862) \\
\hline & & Chromis atrilobata Gill, 1862 \\
\hline & & Microspathodon dorsalis (Gill, 1862) \\
\hline & & Stegastes flavilatus (Gill, 1862) \\
\hline & & Stegastes rectifraemum (Gill, 1862) \\
\hline
\end{tabular}

\begin{tabular}{|c|c|c|c|}
\hline 0.025 & 0.011 & - & 0.036 \\
\hline - & 0.006 & - & 0.006 \\
\hline 0.006 & - & - & 0.006 \\
\hline 0.013 & - & 0.006 & 0.006 \\
\hline 0.006 & - & - & 0.006 \\
\hline - & 0.138 & - & 0.138 \\
\hline 0.013 & - & 0.013 & - \\
\hline 0.238 & 0.305 & 0.406 & 0.136 \\
\hline 0.056 & - & - & 0.056 \\
\hline- & 0.033 & 0.033 & - \\
\hline - & 0.008 & 0.008 & - \\
\hline- & 0.513 & 0.513 & - \\
\hline- & 0.148 & 0.058 & 0.09 \\
\hline - & 0.025 & - & 0.025 \\
\hline- & 0.075 & 0.075 & - \\
\hline 0.248 & 0.114 & 0.146 & 0.216 \\
\hline 0.065 & 0.167 & 0.188 & 0.044 \\
\hline 0.027 & 0.005 & 0.015 & 0.018 \\
\hline 0.013 & - & - & 0.013 \\
\hline - & 0.005 & - & 0.005 \\
\hline - & 0.042 & 0.042 & - \\
\hline 0.565 & 0.106 & 0.565 & 0.106 \\
\hline 0.044 & 0.100 & 0.115 & 0.029 \\
\hline 0.308 & 0.64 & 0.771 & 0.178 \\
\hline 0.135 & 0.110 & 0.188 & 0.058 \\
\hline
\end{tabular}

490 García-Hernández et al.

Macroalgae, benthic macroinvertebrates and fish assemblages at two tropical rocky reefs 
Appendix 1. Continued / Continuación

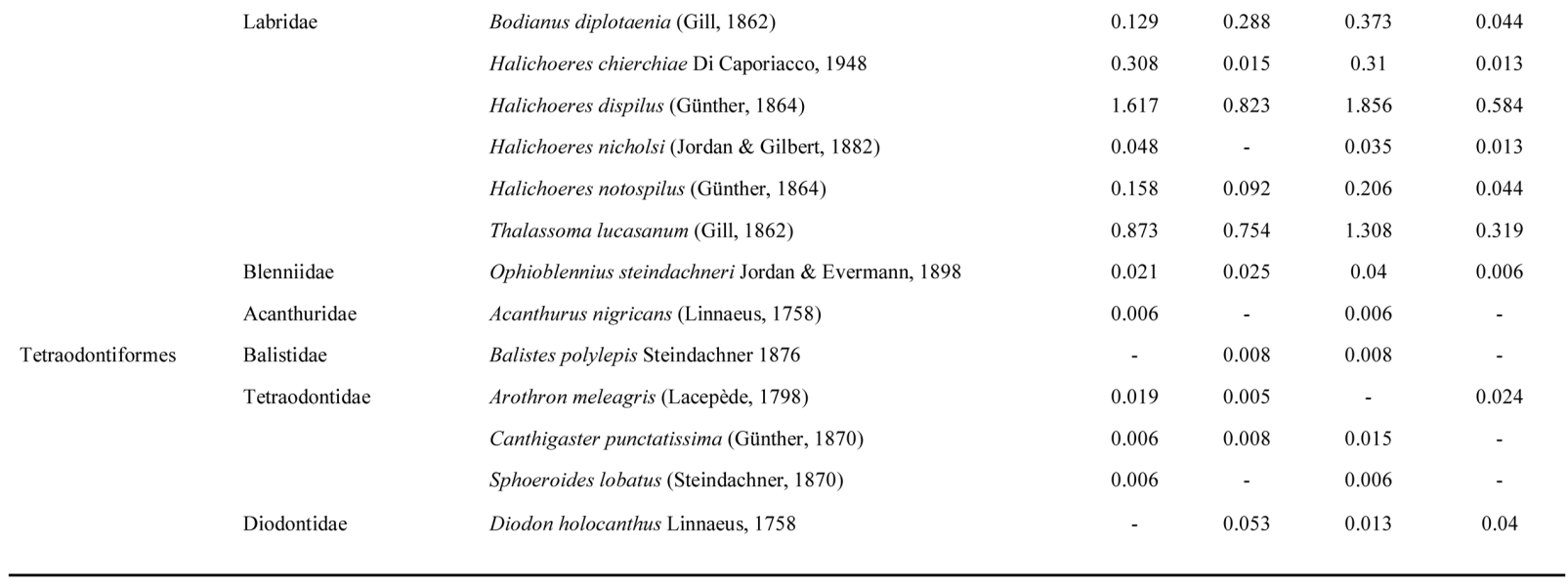

Vol. 49, № 3, 2014 